\title{
Peningkatan Kemampuan Lari Melalui Metode Demontrasi pada Siswa Kelas V di SDN 1 Gemaharjo Kecamatan Watulimo Kabupaten Trenggalek
}

\author{
Bambang Sujianto \\ SDN 1 Gemaharjo Kecamatan Watulimo Kabupaten Trenggalek, Indonesia \\ Email: bambangsujianto215@gmail.com
}

\begin{abstract}
Abstrak: Penelitian ini dilakukan mengingat tingkat ketuntasan belajar siswa yang dapat dicapai hanya sebesar $58 \%$ dari ketuntasan klasikal yang ditentukan sebesar $85 \%$. Sedangkan untuk ketuntasan minimal individual sebesar 75. Kiranya bukan hal terlalu tinggi apabila guru menetapkan tingkat ketuntasan klasikal sebesar $85 \%$ tersebut. Mengingat materi lari kiranya bukanlkah hal yang asing bagi siswa, selalu dilakukan sehar-hari dan hanya tinggal mempelajari teknik yang sesuai saja. Penelitian yang dilaksanakan ini menggunakan Penelitian Tindakan Kelas (PTK). Penelitian Tindakan kelas (PTK) atau Classroom Action Research merupakan penelitian tindakan, dimana hasil penelitian yang dilakukan ditekankan pada adanya tindakan dari guru. Hasil penelitian

\begin{tabular}{l}
\hline Tersedia Online di \\
\hline http://journal.unublitar.ac.id/pendidikan \\
\hline /index.php/Riset_Konseptual \\
\hline Sejarah Artikel \\
\hline Diterima pada : 04-07-2020 \\
Disetuji pada : 29-07-2020 \\
Dipublikasikan pada :31-07-2020 \\
\hline Kata Kunci: \\
\hline Kemampuan Lari, Metode Demontrasi, siswa \\
SD \\
DOI: \\
http://doi.org/10.28926/riset_konseptual.v4i3.2 \\
62
\end{tabular}
menunjukkan terjadi peningkatan pada beberapa aspek yang diteliti, yakni pada tingkat ketuntasan klasikal sebesar 25\%, dan pada nilai rata-rata sebesar 7,6 dan Pada aspek modus dan nilai tertinggi dan nilai terendah teta, tidak ada perubahan. Berdasarkan hasil penelitian dapat disimpulkan bahwa terdapat peningkatan pada kemampuan lari siswa setelah diterapkan metode demostrasi, sehingga metode tersebut efektif.
\end{abstract}

\section{PENDAHULUAN}

Mata pelajaran pendidikan jasmani merupakan mata pelajaran yang menyenangkan bagi sebagian siswa karena proses pembelajaran umumnya dilaksanakan di luar kelas. Mata pelajaran ini membutuhkan banyak praktek di lapangan dengan melakukan olahraga-olahraga yang sudah terdapat pada rencana kegiatan pembelajaran seperti halnya pada materi lari. Olahraga dan pendidikan jasmani diperlukan dalam kehidupan sehari-hari untuk mengembangkan keterampilan pengelolaan diri dalam upaya pemeliharaan kebugaran jasmani serta pola hidup sehat dan mengembangkan sikap sportif, jujur, disiplin,bertanggung jawab, kerja sama, percaya diri, dan demokratis (Sitepu, 2018).

Penelitian ini dilakukan untuk meningkatkan kemampuan lari siswa melalui metode demonstrasi. Berdasarkan hasil observasi awal diketahui bahwa tingkat ketuntasan belajar siswa yang dapat dicapai hanya sebesar $58 \%$ dari ketuntasan klasikal yang ditentukan sebesar $85 \%$. Sedangkan untuk ketuntasan minimal individual sebesar 75 . Kiranya bukan hal terlalu tinggi apabila guru menetapkan tingkat ketuntasan klasikal sebesar $85 \%$ tersebut. Mengingat materil ari kiranya bukanlkah hal yang asing bagi siswa, selalu dilakukan sehar-hari dan hanya tinggal mempelajari teknik yang sesuai saja.

Pada tahap prasiklus pembelajaran dilakukan dengan pemberian tugas, dengan materi "Sepak Bola". Proses pembelajaran dilakukan dengan cara guru mengadakan Tanya jawab dengan siswa, tentang pemahaman dan oengalaman siswa dalam bermain sepak bola. Mempertimbangkan jawaban siswa yang sudah 
cukuppaham dengan permainan sepak bila, guru memutuskan untuk langsung menyuruh siswa bermain sepak bola. Kemuduia guru mengerjakan tugas lainnya.

Pada pertemuan berikutnya, guru mengadakan evakluasi, dan ternyata hasilnya jauh dari harapan. Untuk itu pada pembelajaran berikutnya, yakni materi "Lari", guru menentukan pola pembelajaran dengan menggunakan metode pembelajaran atau model pembelajaran lain, yakni demonstrasi. Dengan mengunakan metode demonstrasi ini, diharapkan akan mampu mendorong meningkatkan prestasi belajar siswa. "Metode demonstrasi adalah pertunjukan tentang proses terjadinya suatu peristiwa atau benda sampai pada penampilan tingkah laku yang dicontohkan agar dapat diketahui dan dipahami oleh peserta didik secara nyata atau tiruannya (Djamarah, 2008:210)."

Berangkat dari kutipan di atas, demonstrasi merupakan metode pembelajaran yang berupaya agar suatu tingkah laku dapat dipahami secara nyata. "Tingkah :Laku" yang dimaksud disini merupakan suatu aktifitas pembelajaran. Adanya demonstrasi atau contoh-contoh yang diberikan oleh guru mengenai proses sesuatu, alan mempermudah siswa dalam memahami materi yang dikaji. Metode demonstrasi adalah metode mengajar dengan cara memperagakan barang, kejadian, aturan, dan urutan melakukan suatu kegiatan, baik secara langsung maupun melalui penggunaan media pengajaran yang relevan dengan pokok bahasan atau materi yang sedang disajikan (Muhibbin Syah, 2000:22).

Pada kutipan yang kedua ini tersirat dan tersurat bahwa metode demonstrasi merupakan cara mengajar dengan memperagakan sesuatu. Adanya peragaan yang dicontoihkan guru yang kemudian diikuti oleh siswa, tentunya akan membawa pembelajaran menjadi lebih bermakna. Sementara menurut Syaiful Bahri Djamarah, bahwa metode demonstrasi adalah metode yang digunakan untuk memperlihatkan sesuatu proses atau cara kerja suatu benda yang berkenaan dengan bahan pelajaran. (Djamarah, 2008:209).

Berdasarkan uraian diatas maka penulis bermaksud melakukan penelitian tindakan kelas dengan judul "Peningkatan Kemampuan Lari Melalui Metode Demontrasi pada Siswa Kelas V Semester I Tahun Pelajaran 2017/2018 di SDN 1 Gemaharjo Kecamatan Watulimo Kabupaten Trenggalek". Adapun tujuan dari penelitian ini adalah untuk memperoleh gambaran yang benar-benar objektif mengenai kemampuan dalam melakukan gerakan lari . bagi Siswa Kelas V Semester 1 Tahun Pelajaran 2017/2018 SDN 1 Gemaharjo Kecamatan Watulimo Kabupaten Trenggalek.

\section{METODE}

Penelitian yang dilaksanakan ini menggunakan Penelitian Tindakan Kelas (PTK). Penelitian Tindakan kelas (PTK) atau Classroom Action Research merupakan penelitian tindakan, dimana hasil penelitian yang dilakukan ditekankan pada adanya tindakan dari guru. Penelitian Tindakan Kelas merupakan tindakan yang dilakukan oleh guru pada saat pembelajaran, dan bertujuan untuk memperbaiki kualitas pembelajaran itu sendiri.

Menurut Suharsimi Arikunto, Penelitian Tindakan Kelas (PTK) adalah suatu pencermatan terhadap kegiatan belajar berupa suatu tindakan, yang sengaja dimunculkan dan terjadi dalam suatu kelas secara bersama (Arikunto, 2011:3).

Sedangkan menurut Tim Pelatih Poyek PGSM, PTK adalah suatu bentuk kajian yang bersifat reflektif oleh pelaku tindakan yang dilakukan untuk meningkatkan kemantapan rasional dari tindakan mereka dalam melaksanakan tugas, memperdalam pemahaman terhadap tindakan-tindakan yang dilakukan itu,seta memperbaiki kondisi dimana praktek pengajaran tersebut dilakukan (Mukhlis, 2003:3).

Penelitian ini merupakan penelitian tindakan kelas (PTK). Pada Penelitian Tindakan Kelas (PTK) ini direncanakan berlangsung selama 2 bulan. Siklua I pertemuan 1 dan 2 dilakukan pada Minggu II bulan Agustus 2017. Siklus II pertemuan 1 dan 2 dilaksanakan pada Minggu III Agustus 2017. 
Untuk keterangan yang lebih rinci rinci dapat dilihat pada jadual berikut:

Tabel 1. Jadwal kegiatan

\begin{tabular}{|l|l|l|}
\hline NO & TANGGAL & KEGIATAN YANG DILAKUKAN \\
\hline 1 & Minggu I Agustus 2017 & Kegiatan Pra Siklus \\
\hline 2 & Minggu II Agustus 2017 & Kegiatan siklus I Pertemuan 1 dan 2 \\
\hline 3 & Minggu II Agustus 2017 & Kegiatan Siklus I Pertemuan 1 dan 2 \\
\hline 4 & $\begin{array}{l}\text { Minggu II Agustus - Minggu II } \\
\text { September 2017 }\end{array}$ & Penyusunan laporan PTK \\
\hline 5 & Minggu III September & Finishing Laporan \\
\hline 6 & Minggu II Oktober 2017 & Seminar \\
\hline
\end{tabular}

\section{A. Hasil Penelitian Pra Siklus}

\section{HASIL DAN PEMBAHASAN}

\section{Perencanaan}

Materi pada tahap pra siklus adalah sepak bola. Pembel;ajaran dilakukan dengan metode pemberian tugas. Perencanaan dilakukan dengan tujuan agar penelitian dapat terlaksana dengan lancar. Aktifitas yang dilakukan pada tahap ini adalah sebagai berikut:

(1) Menyiapkan silabus pembelajaran

(2) Menyiapkan Rencana Pelaksanaan Pembelajaran

(3) Menyiapkan instrument penilaian yang berupa lembar tes pilihan ganda

(4) Menyiapkan instrument penilaian yang berupa lembar pengamatan.

\section{Pelaksanaan Tindakan}

Pelaksanaan tindakan siklus I dilaksanakan dengan menerapkan metode diskusi kelompok, dengan KKM 70. Hasil dari test akhir pada tahap pra siklus adalah: Tabel 2. Hasil Test Pra Siklus

\begin{tabular}{llllllll}
\hline NILAI & $\mathbf{f}$ & \% & Fx & T & $\%$ & TT & $\%$ \\
\hline $\mathbf{1 0 0}$ & 4 & 33 & 400 & 7 & 58 & 5 & 42 \\
$\mathbf{9 0}$ & 0 & 0 & 0 & & & & \\
$\mathbf{8 0}$ & 3 & 25 & 240 & & & & \\
$\mathbf{7 0}$ & 3 & 25 & 210 & & & & \\
$\mathbf{6 0}$ & 0 & 0 & 0 & & & & \\
$\mathbf{5 0}$ & 2 & 17 & 100 & $\begin{array}{l}\text { Rata- } \\
\text { rata }\end{array}$ & 79.16667 & & \\
& 12 & 100 & 950 & & & & \\
\hline
\end{tabular}
berikut:

Berdasarkan tabel di atas, peneliti dapat menyampaikan hal-hal sebagai

1. Siswa yang mencapai nilai 100 sebanyak 4 siswa (33\%)

2. Siswa yang mencapai nilai 90 sebanyak 0 siswa (36\%).

3. Siswa yang mencapai nilai 80 sebanyak 3 siswa (25\%).

4. Siswa yang mencapai nilai 70 sebanyak 3 siswa $(25 \%)$

5. Siswa yang mencapai nilai 60 sebanyak 0 siswa $(9 \% \%)$

6. Siswa yang mencapai nilai 50 sebanyak 2 siswa (17\%)

Berdasarkan data tersebut, maka sebanyak 7 (58\%) siswa sudah tuntas dalam belajar dan sebanyak $5(42 \%)$ siswa belum tuntas dalam belajar. Sedangkan ketuntasan kelas disyaratkan sebesar $85 \%$. Dengan demikian maka pada tahap pra siklus ketuntasan belajar be;lum tercapai.

Pada tahap pra siklus, refleksi yang dapat disampaikan adalah:

1. Guru sibuk dengan tugasnya yang lain

2. Siswa tidak tertantang karena guru tidak dapat menunggui saat permainan berlangsung 


\section{B. Siklus I}

Materi pada siklus I adalah: "Tahapan lari jarak pendek". KKM pada materi ini adalah 75. Metode yang digunakan demonstrasi. Langkah-langkah dari masing-masing tahap adalah sebagai berikut:

\section{Tahap Perencanaan}

Tahap perencanaan ini dilakukan dengan:

1) Menyusun silabus

2) Merencanakan pembelajaran yang disusun dalam RPP.

3) Menyiapkan daftar hadir siswa

4) Menyiapkan Instrumen penilaian.

5) Menyiapkan daftar hadir siswa

\section{Tahap Pelaksanaan}

Pertemuan 1:

Pelaksanaan pada siklus ini sesuai dengan model pembelajaran yang telah ditentukan, yakni demonstrasi. Adapun langkah-langkahnya adalah:

1. Guru mengucapkan salam pembuka

2. Siswa berbaris bersyaf

3. Siswa berdoa

4. Siswa melakukan pemanasan

5. Guru menuliskan tujuan pembelajaran yakni mengidentifikasi lari jarak $100 \mathrm{~m}$

6. Guru menjelaskan cara menerapkan model pembelajaran demonstrasi

7. Guru mendemonstrasikan cara-cara melaksanakan lari jarak $100 \mathrm{~m}$

8. Siswa secara bergantian mendemonstrasikan

9. Guru membentuk kelompok

10.Guru membimbing siswa untuk melakukan demonstrasi dalam kelompok (anggota kelompok yang lain memperhatikan)

11. Guru dan siswa membuat suatu kesimpulan.

12.Guru menyampaikan materi untuk pertemuan berikutnya yang merupakan kelanjutan dari pertemuan 1.

Pertremuan 2:

1. Guru mengucap salam

2. Siswa berbaris bersyaf

3. Siswa berdoa

4. Guru mengingatkan tujuan pembelajaran seperti pert.1

5. Siswa melakukan pemanasan

6. Guru menilai siswa yang demonstrasi lari (individu: guru memegang jertas dan bolpoin)

7. Guru dan siswa membuat suatu kesimpulan.

8. Guru mengadakan refleksi

\section{Tahap Pengamatan}

Dalam suatu kelas sudah dapat dipastikan ada siswa yang aktif dan ada siswa yang pasif. Hasil pengamatan yang berkaitan dengan hal tersebut menghasilkan data bahwa sebanyak $55 \%$ siswa aktif dalam pembelajaran. Sedangkan pelaksanaan metode demonsytrasi dapat dilaksanakan sekitar $75 \%$ karena sekali waktu guru masih harus melakukan tugas lainnya. Peneliti mengamati bersamaan dengan proses pembelajaran inti berlangsung.

\section{d. Tahap Refleksi} berikut:

Hasil refleksi dilakukan pada siklus I diawali dengan memperhatikan tabel 
Tabel 3. Hasil Test Siklus I

\begin{tabular}{llllllll}
\hline NILAI & $\mathbf{f}$ & \% & Fx & tts & $\%$ & tt & $\%$ \\
\hline $\mathbf{1 0 0}$ & 5 & 42 & 500 & 8 & 67 & 4 & 33 \\
$\mathbf{9 0}$ & 0 & 0 & 0 & & & & \\
$\mathbf{8 0}$ & 3 & 25 & 240 & & & & \\
$\mathbf{7 0}$ & 2 & 17 & 140 & & & & \\
$\mathbf{6 0}$ & 0 & 0 & 0 & & & & \\
$\mathbf{5 0}$ & 2 & 17 & 100 & rata2 & 81.66667 & & \\
& 12 & 100 & 980 & & & & \\
\hline
\end{tabular}
berikut:

Berdasarkan tabel di atas, peneliti dapat menyampaikan hal-hal sebagai

1. Siswa yang mencapai nilai 100 sebanyak 5 siswa (42\%)

2. Siswa yang mencapai nilai 90 sebanyak 0 siswa (36\%).

3. Siswa yang mencapai nilai 80 sebanyak 3 siswa (25\%).

4. Siswa yang mencapai nilai 70 sebanyak 2 siswa $(17 \%)$

5. Siswa yang mencapai nilai 60 sebanyak 0 siswa $(9 \% \%)$

6. Siswa yang mencapai nilai 50 sebanyak 2 siswa (17\%)

Berdasarkan data tersebut, maka sebanyak 8 siswa (67\%) siswa sudah tuntas dalam belajar dan sebanyak 4 (33 \%) siswa belum tuntas dalam belajar. Sedangkan ketuntasan kelas disyaratkan sebesar $85 \%$. Dengan demikian maka pada tahap pra siklus ketuntasan belajar belum tercapai.

Pada tahap siklus I, refleksi yang dapat disampaikan adalah sebagai berikut:

1. Sebagian besar siswa sudah focus pada pembelajaran, tetapi masih ada beberapa siswa yang kurang focus..

2. Kemampuan siswa dalam melakukan gerakan sudah mengalami peningkatan divanding dengan pra siklus.

3. Karena ketuntasan kjelas belum dapat dicapai, maka penelitian dilanjutkan pada siklusll

\section{Siklus II}

Siklus II membahas materi : “Start dalam lari Jarak Pendek.” KKM tetap 75. Metode pembelajaran demonstrasi. Langkah-langkah dari masing-masing tahap adalah sebagai berikut:

\section{a. Tahap Perencanaan}

Guru merencanakan pembelajaran siklus II dengan beberapa kegiatan, antara lain sebagai berikut:

1) Menyusun silabus

2) Merencanakan pembelajaran yang disusun dalam RPP sesuai hasil refleksi siklus I

3) Menyiapkan daftar hadir siswa

4) Menyiapkan alat evaluasi

5) Menyiapkan daftar hadir siswa

\section{b. Tahap Pelaksanaan}

\section{Pertemuan 1:}

Adapun langkah-langkahnya adalah sebagai berikut: Guru mengucap salam, siswa berbaris bersyaf, siswa berdoa, guru menuliskan tujuan pembelajaran, siswa melakukan pemanasan, guru menjelaskan cara menerapkan model pembelajaran demonstrasi, guru mendemonstrasikan cara-cara melaksanakan start lari jarak pendek, siswa secara bergantian mendemonstrasikan, guru membentuk kelompok, guru membimbing siswa untuk melakukan demonstrasi dalam kelompok (anggota kelompok yang lain memperhatikan), guru dan siswa membuat suatu kesimpulan, terakhir guru menyampaikan materi untuk pertemuan berikutnya. 


\section{Pertemuan 2:}

Adapun langkah-langkahnya adalah sebagai berikiut :

1. Guru mengucap salam

2. Siswa berbaris bersyaf

3. Siswa berdoa

4. Siswa melakukan pemanasan

5. Guru mengingatkan tujuan pembelajaran seperti pada pertemuan 1.

6. Guru menilai siswa yang demonstrasi lari.

7. Guru dan siswa membuat suatu kesimpulan.

8. Guru mengadakan refleksi

\section{b. Tahap Pengamatan}

Pada siklus II, siswa sangat aktif dalam belajar, dapat melakukan gerakan dengan sungguh-sungguh. Sedangkan guru juga sangat focus dalam mengajar, tidak terbebani dengan tugas lain. Dengan demikian kondisi pembelajaran sangat kondusif.

\section{d. Refleksi}

Hasil refleksi pada siklus II diawali dengan memperhatikan tabel: Tabel 4. Hasil Test Siklus II

\begin{tabular}{llllllll}
\hline & $\mathbf{f}$ & $\%$ & $\mathbf{F x}$ & tts & $\%$ & tt & $\%$ \\
\hline $\mathbf{1 0 0}$ & 7 & 58 & 700 & 11 & 92 & 1 & 8 \\
$\mathbf{9 0}$ & 0 & 0 & 0 & & & & \\
$\mathbf{8 0}$ & 4 & 33 & 320 & & & & \\
$\mathbf{7 0}$ & 0 & 0 & 0 & & & & \\
$\mathbf{6 0}$ & 0 & 0 & 0 & & & & \\
$\mathbf{5 0}$ & 1 & 8 & 50 & $\begin{array}{l}\text { Rata- } \\
\text { rata }\end{array}$ & 89.16667 & & \\
& 12 & 100 & 1070 & & & & \\
\hline
\end{tabular}

Sumber Data : Hasil test akhir siklus II

Berdasarkan tabel di atas, peneliti dapat menyampaikan hal-hal sebagai berikut:

1. Siswa yang mencapai nilai 100 sebanyak 7 siswa (58\%)

2. Siswa yang mencapai nilai 90 sebanyak 0 siswa $(0 \%)$.

3. Siswa yang mencapai nilai 80 sebanyak 4 siswa (33\%).

4. Siswa yang mencapai nilai 70 sebanyak 1 siswa (8\%)

5. Siswa yang mencapai nilai 60 sebanyak 0 siswa $(0 \%)$

6. Siswa yang mencapai nilai 50 sebanyak 1 siswa $(8 \%)$

Berdasarkan data tersebut, maka sebanyak 11 (92\%) siswa sudah tuntas dalam belajar dan sebanyak 1 (8\%) siswa bellum tuntas dalam belajar. Sedangkan ketuntasan klasikal yang disyaratkan adalah 85\%. Modus berada pada nilai 100 , sebanyak 7 siswa (58\%).

Pada tahap siklus II, refleksi yang dapat disampaikan adalah sebagai berikut:

1. Guru dapat focus dalam mengajar

2. Siswa sangat fokus dalam belajar.

3. Peningkatan kemampuan siswa sudah meningkat dengan maksimal.

4. Ketuntasan kelas dapat tercapai. Dengan demikian maka penelitian dihentikan pada siklus II.

\section{Perbandingan Hasil Belajar Siswa pada Siklus I dan Siklus II}

Beberapa perbandingan berikut dilaksanakan untuk mengetahui peningkatan hasil penelitian dari siklus I ke siklus II. Perbandingan yang dimaksud adalah sebagai berikut: 
Tabel 5. Perbandingan Ketuntasan belajar siswa Siklus I \& Siklus II

\begin{tabular}{lllll}
\hline NO & Aspek & Siklus I & Siklus II & Ketr \\
& & & & \\
\hline $\mathbf{1}$ & Ketuntasan & $67 \%$ & $92 \%$ & Naik 25\% \\
$\mathbf{2}$ & Rata-Rata & 81,6 & 89,2 & Naik 7,6 \\
$\mathbf{3}$ & Modus & 100 & 100 & Tetap \\
$\mathbf{4}$ & Nilai Terendah & 50 & 50 & Naik 20 \\
$\mathbf{5}$ & Nilai Tertinggi & 100 & 100 & Tetap \\
\hline
\end{tabular}

Berdasarkan nilai pada tabel di atas maka dapat disimpulkan bahwa terjadi peningkatan pada beberapa aspek yang diteliti, yakni pada tingkat ketuntasan klasikal sebesar $25 \%$, pada nilai rata-rata sebesar 7,6 . Selain itu pada aspek modus, nilai tertinggi dan nilai terendah tetap dan tidak mengalami perubahan.

\section{KESIMPULAN}

Hasil penelitian yang telah dikaji pada Bab IV dapat disampaikan ulang sebagai berikut: Terjadi peningkatan pada beberapa aspek yang diteliti, yakni pada tingkat ketuntasan klasikal sebesar $25 \%$, dan pada nilai rata-rata sebesar 7,6 dan Pada aspek modus dan nilai tertinggi dan nilai terendah teta, tidak ada perubahan. Berdasarkan hasuil penelitian tersebut, maka dapat disampaikan kesimpulan bahwa : "Penerapan metode demonstrasi dapat meningkatkan kemampuan Lari bagi siswa kelas V Di SDN 1 Gemaharjoi Kecamatan Watulimo Kabupaten Trenggalek Semester I Tahun Pelajaran 2017/2018. Manfaat penelitian ini diharapkan dapat meningkatkan semangat dan motivasi belajar siswa, memberikan pengalaman yang lebih menarik bagi siswa, serta dapat meningkatkan kemampuan melakukan gerakan lari dengan menggunakan teknik yang tepat. Bagi guru untuk menambah wawasan tentang metode mengajar yang dapat diterapkan dalam pembelajaran, terutama metode demostrasi. Selain itu juga memberikan nilai tambah bagi guru untuk belajar menyusun suatu ide/gagan dalam bentuk karya tulis. Sedangkan bagi Sekolah untuk meningkatkan motivasi kepada para guru, bukan hanya pada peneliti untuk meningkatkan kinerja dengan cara melakukan inovasi pembelajaran agar hasil yang dicapai dapat benar-benar maksimal.

\section{DAFTAR RUJUKAN}

Arikunto, 2011. Penelitian Tindakan kelas. Yogyakarta:Teras

Sitepu, Yuni Intan Sari Br. (2018). Penerapan Metode Bermain Untuk Meningkatkan Hasil Belajar Siswa Pada Mata Pelajaran Penjas Materi Lari Sprint Kelas V SD Negeri 057188 Pondok Sinembah Tahun Pelajaran 2017/2018. Skripsi. Universitas Quality Medan

Djamarah, Syaiful Bahri. (2008). Strategi Belajar Mengajar. Jakarta: PT Rhineka Cipta Mukhlis. (2003). Rancangan/rencana awal, sebelum mengadakan penelitian. Malang: Penerbit Universitas Negeri Malang

Syah, Muhibbin. (2000). Model-Model Pembelajaran. Yogyakarta: Teras 